\title{
Relevant Information for the Accountability of Private Institu- tions of Social Solidarity: Results from a Fieldwork
}

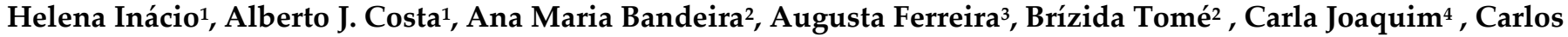 \\ Santos ${ }^{3}$, Cristina Góis 5 , Denise Curi ${ }^{4}$, Deolinda Meira² , Graça Azevedo ${ }^{3}$, Mafalda Jesus ${ }^{6}$, Maria Goreti Teixeira ${ }^{6}$, \\ Patrícia Monteiro ${ }^{6}$, Rúben Duarte ${ }^{4}$ and Rui Pedro Marques ${ }^{4, *}$
}

1 Higher Institute of Accounting and Administration, University of Aveiro; GOCCOPP Research Unit, University of Aveiro, Portugal

2 Polytechnic Institute of Porto, Portugal

3 Higher Institute of Accounting and Administration, University of Aveiro; Centre for Research in Accounting and Taxation of the Polytechnic Institute of Cávado and Ave, Portugal

4 Higher Institute of Accounting and Administration, University of Aveiro, Portugal

5 Polytechnic Institute of Coimbra, Portugal

6 Confederação Nacional das Instituições de Solidariedade, Portugal

* Correspondence: ruimarques@ua.pt

\begin{abstract}
The Social Economy (SE) emerges as an interesting alternative to deal with social problems that often cannot be met by the services provided by the State. However, one of the concerns relates to the ability of these institutions to meet the demands of stakeholders concerning accountability. In this sense, the present work aimed to determine if the IPSS are prepared to meet the management requirements by increasing their accountability. For that purpose, we conducted qualitative research, with an exploratory focus, with 31 Portuguese Private Social Solidarity Institutions (IPSS). The interviews took place between June and July 2019, with those responsible for managing the entities. The interviews were guided on a semi-structured script based on the literature review. After Content Analysis, it was found that, in most of the institutions interviewed, the board does not use management tools, such as performance analysis, social impact assessment, strategic planning and quality management systems, even recognising the importance of using them. The fact is due to the lack of access or knowledge about its use. In addition, the majority of the IPSS interviewed showed concern about the transparency and ethics of managers. Current strategic management practices are remarkably targeted at companies in the for-profit sector and can compromise the principle of investments in human and social issues. Thus, the introduction of new activities can further reinforce the pressure felt by these institutions in carrying out operational activities.
\end{abstract}

Keywords: Accountability; Management; Non-Profit Organisations; Social Economy; Social Solidarity Institutions; Transparency.

\section{Introduction}

The Social Economy (SE) emerges as an interesting alternative to deal with social problems faced by humanity that often cannot be met by the services provided by the State. According to data from the European Union (EU), there are 2 million SE companies in Europe, representing $10 \%$ of all companies operating in the region. They employ more than 11 million people, i.e., about $6 \%$ of the jobs (EU, 2021). These organisations have a primary objective to serve members and not get the return on investment as traditional capital companies (EU, 2021).

SE organisations are, however, intrinsically complex entities due to: diversity of stakeholders they serve; distinct organisational structures; the combination of volunteer and paid employees; dependence on various sources of funding; and complex issues that they seek to address, varying from poverty alleviation and social exclusion to the promotion of human rights, religious beliefs and specific ideologies (Speckbacher, 2003; Hall \& 
O'Dwyer, 2017). This complexity influences the way they are controlled and held accountable for their actions and impacts, consequently, their organisational profile (Hall \& O'Dwyer, 2017). This sophistication suggests that the entity directly connects with its stakeholders to transmit relevant information in terms of management and strategy.

However, it is essential to note that the for-profit sector's management concepts and measurement tools are not always transferable to the non-profit sector (Speckbacher, 2003). Many decisions of SE sector organisations are made taken on non-accounting information, making the accountability process complex since it is supported by factors that are more difficult to quantify, particularly concerning the social results of their activities (Connolly \& Kelly, 2011). Thus, demonstrate the immediate impact of this type of organisation on the community, based on non-accounting information (directional accountability) (Aimers \& Walker, 2008) requires transforming a series of qualitative information into indicators that are easy to understand for its various stakeholders.

While market forces and public policies influence the configuration and behaviour of most non-profit organisations (NPO), their form is generally malleable and flexible and requires a robust internal guidance capability to point it in the right direction and ensure its success over time (Young, 2001). It turns out, however, that in certain situations, such as the death of a founder, the rapid growth of the organisation, or the emergence of new social needs, challenging identity dilemmas can arise, and the resolution of their identity (sometimes new) is crucial for the choice of successful strategies and structures (Young, 2001). Therefore, it is recognised that, in the design of an efficient strategy and cohesive planning, it is necessary to effectively know the field, numbers, changes and development over time.

In the context of the Portuguese SE entities, one of the most important families is represented by the Private Social Solidarity Institutions (IPSS1). The IPSS are a multi-secular reality in Portuguese society and are dispersed throughout the country. However, from the 20th century on, these institutions maintained or increased their activities, but the State assumed political responsibility for social protection through the consecration of rights and various services (Sousa, 2012). The IPSS follow and comply with the same legislation, but with an autonomous management, without inference, but with the supervision of government agencies, namely the Institute of Social Security (ISS).

That said, this work aims to understand whether IPSS are prepared to meet management requirements by increasing their accountability. In this sense, the following research question arises: Are IPSS prepared to meet management requirements by increasing accountability?

To this end, qualitative research was carried out with an exploratory focus from June to July 2019. Thirty-one IPSS were interviewed during this period. The data were submitted to Content Analysis, which allowed classification into six categories.

This paper is divided into five sections as follows: after this first introductory sections, the authors present and clarify the theoretical background that supports this work in the second section; the third section presents the methodology; the data analysis and the findings of the research are presented in the fourth section; and finally, the fifth section presents the final considerations and conclusions.

\section{Literature Review}

\subsection{Terminology employed}

For the literature review, in this paper, consider the terms "Third Sector Organization (TSO)"; "Non-Profit Organisation (NPO)"; "Non-Governmental Organisation (NGO)"; and "Social Economy Organizations (SE)" as synonyms. It is important to note here that NGO are accountably elusive that seem to challenge the definition of SE (Gray, Owen, \& Adams, 2008). The term NGO entered into force in 1945 due to the need for the United Nations (UN) organisation to differentiate in its status rights of participation of specialised

\footnotetext{
1 Acronym in Portuguese for Private Social Solidarity Institutions.
} 
agencies, intergovernmental and international private organisations. A more modern definition describes NGO as a non-profit, voluntary citizen's group that is organized on a local, national, or international level to address issues in support of the public good. Taskoriented and made up of people with a common interest, NGO perform a variety of services and humanitarian functions, bring citizen's concerns to Governments, monitor policy and program implementation, and encourage participation of civil society stakeholders at the community level (UN, 2021).

\subsection{Accountability}

Accountability is a broad and comprehensive concept that refers, among other things, to taking responsibility for the decisions made, explaining and justifying them (Edwards \& Hulme, 1995; Gray, Owen, \& Adams, 2008; Peters, 1983; Bovens, 2016; Santos, Ferreira, Marques, \& do Carmo Azevedo, 2018). Scrutiny and doubts about the public role of NPO a few decades ago have required better accountability on the part of these institutions (Kearns, 1994). Accountability has focused mainly on internal control and auditing, monitoring, evaluation and compliance with standards and regulations (Choudhury \& Ahmed, 2002). According to Edwards and Hulme (1995), the only way NPO can prevent corruption is by developing systems to monitor their performance, accountability and strategic planning to ensure that a line between transparent commitment and blind preference remains drawn.

The trend in recent years has been for NPO around the world to take accountability initiatives and activities that go beyond minimum legal requirements, thereby increasing transparency and good governance, leading to greater trust and reputation (Becker, 2018). In this context, accountability initiatives beyond the legal minimum have gained substance in the last two decades (Becker, 2018). Thus, depending on the legal regulations of each country, a variety of different codes of conduct, self-regulation systems, certification and accreditation have evolved as tools to support good governance in entities in the SE sector.

The NPO need even more management than business companies because they lack the discipline of the final outcome (Speckbacher, 2003).

\subsection{Strategic Management of SE Organisations}

One of the central concepts in the study on business management concerns the strategy and purpose of the organisation (Bartlett \& Ghoshal, 1994).

An organisational strategy is the set of policies and practices to address its purposes (Young, 2001). The strategy cannot be confused with the entity's purpose, which is unique and demonstrates the reason for its existence. The purpose should translate what it hopes to achieve and all its activities that must be developed (Drucker, 1973; Hitt, Ireland, \& Hoskisson, 2012). Usually, the purpose of a SE organisation is not to produce profit but to focus on social objectives, be it poverty reduction, community development, sustainability or health and social assistance (Hall \& O'Dwyer, 2017).

The differences between profitable companies and those belonging to the TSO are sufficient to suggest that NPO may need their own concept of strategy formulation, which differs from for-profit companies. For Moore (2000), among these differences, two are more remarkable: (a) NPO define the value they deliver in terms of the organisation's mission and not according to their financial performance; and (b) they often guarantee their revenue through people who (voluntarily or unintentionally) pay for benefits to people other than themselves, unlike the customer who buys goods for his own benefit.

Mission statements describe what an organisation does to achieve its purpose. These are high-level statements and generally aim to provide a clear and succinct summary of why the organisation exists (Hitt, Ireland, \& Hoskisson, 2012). The mission defines the organisation's value to society and creates the organisation's objective, so in some cases, it becomes the metric used to judge past performance and evaluate future courses of action (Bryce, 2017). However, it cannot be seen as an action plan subject to periodic change. On the contrary, the mission statement must be a contract, a contractual promise, secured on 
its terms until this contract is renegotiated and approved by its component parties (Bryce, 2017). A company is not defined by its name, statute or social contract but rather by its business mission (Drucker, 1973). Only a clear definition of the organisation's mission and purpose makes possible business objectives clear and realistic.

Only a clear definition of the organisation's mission and purpose makes clear and realistic business objectives possible. In general, the missions of NPO are defined in substantive, rather than financial, terms. Thus, the mission, in NPO, has the following properties (Bryce, 2017):

1. Social contract: points to specific public problems that the company seeks to alleviate or the desirable social conditions that the company seeks to achieve (Moore, 2000). Failure to perform this task can lead to termination of status, denial of status, and penalties for management and the organisation.

2. Permanence: it is permanent unless changed by amendments subject to the approval of members, trustees and the public represented by the State.

3. Clarity: a mission statement is always short (with less than 100 words) and clear, pointing to a specific public service.

4. Approval: it must be approved by the directors, trustees and accepted by the State in which the NPO is established.

5. Proof: it is necessary that NPO prove annually their existence, performance, mission fulfilment and report on the use of revenues, expenses and other resources to proceed with it.

In addition, its mission is typically targeted at a specific group of clients or beneficiaries, such as a local community of individuals with particular social or health needs, which makes effectiveness and impact measures involve assessing how the organisation impacted these groups (Hall \& O'Dwyer, 2017; Werther \& Berman, 2001); it also becomes necessary to ascertain why the organisation has embraced this cause (Werther \& Berman, 2001). In this way, the mission must contain at least three elements: for whom the entity works, what the entity delivers, and how the entity delivers.

The strategy adopted by an institution depends on developing a clear mission for the organisation and the definition of its strategic objectives. The mission should be transformed into detailed support objectives that drive the entire organisation (Hitt, Ireland, \& Hoskisson, 2012; Drucker, 1973). They should identify the 'what' and the 'why' of their social responses.

The strategic vision should seek to balance the interests of the different stakeholders to ensure the continuity of participation of each one. While the mission is the reason for the organisation's existence, the visions represent the desired generic purposes, for which the company's efforts are guided (Werther \& Berman, 2001). In the formation stage of an $\mathrm{NPO}$, the vision usually reflects a notion of grand purpose (glory) but evolves to embrace critical constituents. As the organisation succeeds and matures, the vision can be expanded to a larger purpose or domain (Werther \& Berman, 2001).

This expansion typically reflects the organisation's growing success and pressures placed on internal constituents (such as managers, professionals, and staff) and external forces (such as funding sources, clients, board members, community expectations). While the founder or those involved in the training stage may see this expansion of vision as desirable, they may also see it as a dilution of the organisation's original mission (Werther \& Berman, 2001). The vision booster is usually the founder or founding group. With the most excellent maturity, the vision becomes increasingly institutionalised and driven by employees and supporters and less by the founders (Werther \& Berman, 2001).

As for the objectives and challenges of organisations, it is suggested that they be established, at an early stage, in a very spontaneous way, as occurs in brainstorming. Nevertheless, as you get to basic ideas, it becomes vital to hierarchise the objectives and challenges within certain classifications through debates. Oliveira (2010) suggests four levels for the objective hierarchy process: mission, company objectives, functional objectives, and challenges. 
Thus, based on the assumptions of Hitt, Ireland, \& Hoskisson (2012), that the strategy must start from the development of a clear mission and its strategic objectives, and, added to the fact that the vision is related to the maturity of the institution (Werther \& Berman, 2001), it is advocated that the existence of mission, vision and strategic objectives may indicate that the institution has a strategic plan. Moreover, it is justified that the mission maturity may be related to the presence of the elements: to whom the entity works, what the entity delivers, and how the entity delivers (Werther \& Berman, 2001).

For a strategic approach that allows us to see the organisation from a broad perspective, covering its leadership and its constraints, some questions are needed, such as (Werther \& Berman, 2001):

1. How is the non-profit trying to achieve its goals?

2. What are the expectations of those who support the organisation?

3. What strategies are available to the organisation?

4. What roles do leaders play?

5. What resources does the organisation have to support its goals?

Thus, you can understand how successful NPO achieve success. However, it is necessary to consider that 'best practices' are just one of several factors that determine how NPO achieve their goals (Werther \& Berman, 2001).

However, organisations need to know whom they are by defining their organisational identity (Young, 2001). The organisational profile should provide an overview of organisational characteristics by reporting primary activities and identifying how these activities relate to the organisation's mission and key strategic objectives (e.g., poverty reduction, environment, human rights, among others) (GRI 4, 2013).

Organisational identity can be defined as what is central, distinct and lasting about an organisation (Albert \& Whetten, 1985) or, also, is related to the organisational role or function and can even be described in terms of what an organisation does, or "what business it is in" (Young, 2001). Behind their identity, there must be a certain flexibility that allows NPO to choose whom they want to be among several possible organisation (Young, 2001). Identity is a distinct but holistic concept that integrates, supports and drives several operational and management concepts that guide the direction and character of a longterm organisation (Young 2001).

SE organisations occupy a unique space within the economy, where, as companies, they are driven by the need to be financially sustainable, but like NPO, they use economic surpluses to boost social and environmental growth (Zainon, et al., 2014). In this context, it should be emphasised that financial crises may call into question the identity of the NPO (Young, 2001). To resolve any financial deficits, these organisations often find ways to supplement their funding sources (governmental or philanthropic) through activities that complement their main activity. However, it should be noted that this 'complement' should have its sole purpose to meet its social mission.

\subsection{Strategic Planning}

Faced with a dynamic and complex operational environment, NPO are increasingly attentive to their organisational sustainability (Al-Tabbaa, 2012; Claeyé \& Jackson, 2012) at long-time vision. To meet the needs of the external environment, strategies are needed to enable these organisations to remain effective and achieve their purposes (Moore, 2000). In this sense, the personnel, governance and financial requirements of a social purpose organisation follow its identity (Young, 2001).

Strategic planning will help the board of directors reflect on the social interests associated with the mission and the skills to fulfil it. The staff need to meet its purposes, as well as its experience and sensitivity to the social problems being addressed; be aware of the business problems faced by the organisation; engage volunteers with the cause; and assess the necessary funding, which should include additional government donations, as well as charitable funds for the same reason (Allison \& Kaye, 2015; Bryson, 2018). 
The use of strategic management tools can help SE organisations to find a better balance and ensure their long-term sustainability. They should focus on the impact of sustainability trends, risks and opportunities on the organisation's long-term perspectives and financial performance. Strategic planning will provide the paths, courses and action programmes that must be followed in place to achieve the objectives and challenges set by the organisation (GRI 4, 2013). However, as current strategic management practices are notably oriented towards companies in the lucrative sector, they can compromise the principle of investments in human and social issues (Kong, 2008).

\subsection{Quality Management System}

One of the management tools that has shown a growing interest among SE organisations is the Quality Management Systems (QMS) and Excellence (Al-Tabbaa, Gadd, \& Ankrah, 2013; Cairns, Harris, Hutchison, \& Tricker, 2005). This interest may be justified by increased competition between these organisations to obtain scarce resources; intensifying pressure from funders, government agencies and other stakeholders to provide services effectively; and higher user needs for providers to deliver value for money.

QMS models see performance improvement as an approach to combat this difficult environment (Cairns, Harris, Hutchison, \& Tricker, 2005; Kong, 2008). Total Quality Management (TQM) is suggested as a more holistic approach to relevant performance improvement as it encompasses social and technical issues (Bou-Llusar, Escrig-Tena, RocaPuig, \& Inmaculada, 2005).

Thus, developing institutional tools to help NPO work on their identity-related issues is of paramount importance. Thus, its definition and articulation should be the first responsibility of senior management (Bartlett \& Ghoshal, 1994). In this work, it is assumed that the manual of functions is an integral part of the QMS, but it is admitted that, in some situations, organisations have a manual of functions without having a QMS. The same reasoning was adopted concerning the global performance assessment (Kong, 2008).

\subsection{Governance}

Governance issues are relevant to all organisations but are of particular concern to NGO concerning the 'values' to which they aspire but also in terms of resource management and performance (GRI 4, 2013). The current concern with organisational/corporate governance can be attributed to the (Spear, 2004):

1. "excessive executive power that can culminate in abuse of pension funds, substantial remuneration packages for executives, corrupt practices, as well as poor decisionmaking;

2. a concern that systems that try to allow owners to exercise control over managers have often been ineffective and complex;

3. a concern that, with the increase in the globalisation of corporations and the relatively weak regulatory powers of national governments, some effective restriction on the power of corporate managers is necessary; and

4. a growing concern for the environment and the failing market for common property (the tragedy of the commons); and thus, put more significant needs on a good administration".

The purpose is the centrepiece of corporate governance in SE, and its purpose is to provide a set of rules, principles and institutions that make their processes more efficient while at the same time generating value for their relevant stakeholders (Speckbacher, 2008). By learning more about the reasons for possible inefficiencies in NPO, one can discuss which governance mechanisms help facilitate cooperation and have improved engagement among stakeholders (Speckbacher, 2008).

Organisational governance is the result of the composition and behaviour of the board of directors and how to deal with stakeholders' expectations. Governance performance is a specific behaviour domain. Good governance practises are expected to positively impact organisational decision-making, positively influencing the organisation's 
other performance areas (Crucke \& Decramer, 2016). However, it is observed that governance practices targeted at for-profit organisations can be detrimental to the mission of SE organisations (Wolf \& Mair, 2019).

The different stakeholders expect NGO's decision-makers to ensure that their organisation reflects the diversity of the society in which they operate and to act with equity and integrity in their leadership and management (GRI 4, 2013). The board must bring together an ethical framework for all aspects of governance to pursue its objective effectively and correctly (Hitt, Ireland, \& Hoskisson, 2012). On the other hand, governance deficiencies can damage the organisation's reputation and fundraising capacity and make it difficult to achieve its objectives (Rassart \& Miller, 2013).

Therefore, NPO should not only be well-governed but should be seen to be well governed due to (Rassart \& Miller, 2013):

- reducing funding from traditional sources such as governments, corporations and private donors;

- competition from other NPO facing similar funding difficulties;

- increasing demand for services, resulting from reduction or cuts in programs by governments;

- $\quad$ need to manage more complex and sophisticated entities, as many NPO has grown in size and complexity;

- greater responsibility and expectations on the part of an increasing number of stakeholders, who may have conflicted expectations for the organisation;

- rapid dissemination of information across social media, which can quickly affect the way the organisation is viewed; and

- difficulty in recruiting quality board members, who may choose not to join the organisation's board for time constraints or liability concerns.

Oversight of financial management concerning governance is seen by NPO stakeholders as especially important, given that many NPO rely on donors or public support. In addition to the responsibility to comply with laws and regulations, it is clear that there is a need for high and balanced accountability measures not only for donors but also for other critical stakeholders affected, the community and society at large (GRI 4, 2013).

In NPO, the social bodies are primarily volunteers. However, their responsibilities and associated liabilities - are generally not (Rassart \& Miller, 2013). The remuneration of the corporate bodies reflects the incorporation of ethical aspects. It is expected that there will be a balance between the responsibilities assumed and the perceived remuneration.

Although women have historically played essential roles in the charity work (Themudo, 2009), there are fewer women holding positions of executive directors and board members when compared to the number of men in those positions (Pynes, 2000), and there are pay gaps (although not as pronounced as in the lucrative sector) (Lewis, Edwards, Lewis, B., \& McGinnis, 2013). The strength of NPO is directly related to women's empowerment and their relative position in society (Themudo, 2009). Women generally reveal stronger preferences for equity and collective goods than men, and the higher society's demand for social products and the lower the participation of governments, the more women enter this area (Themudo, 2009). However, few scientific studies address this issue, since this, it is understood that a Framework to evaluate SE organisations should contemplate parity between women and men in social bodies.

The discussion about workers' participation in the management bodies is related to the agency's theory, or even the view of the shareholder (Friedman, 1970) versus the stakeholder view (Freeman, 1999). The shareholder's view emphasises shareholder value as the company's goal, in contrast to the stakeholders' perspective, argues that an equally legitimate goal is to serve the interests of employees and other stakeholders. Thus, while employee participation is a logical phenomenon from the point of view of stakeholders, from the shareholders' point of view, it is only considered desirable when it serves the interests of shareholders (Kleinknecht, 2015).

In SE organisations, the founders' interests are oriented towards social causes, which should be aligned with the interests of employees. In addition, for an organisation to 
effectively and appropriately pursue its purpose, people involved in the organisation must share a common understanding of how this is done (Campbell \& Alexander, 1997; Ireland \& Hitt, 1999). For that purpose, an organisation will have to have values that express what the organisation considers suitable and principles that express what the organisation considers correct (Hitt, Ireland, \& Hoskisson, 2012).

Together with the purpose, these values and principles form the ethical structure of an organisation. This structure guides the people's decisions and should be reflected in their policies, systems, and processes (Hitt, Ireland, \& Hoskisson, 2012). Since councils are mechanisms for employee participation (or at least a critical analysis of) decisions at the organisation's level, it seems sensible to say that it is essential to assess whether workers are involved in the governing bodies (Kleinknecht, 2015).

Corporate governance practices are primarily determined nationally through (different) legal norms (Porta, Lopez-de-Silanes, Shleifer, \& Vishny, 1998).

\subsection{Transparency}

Finally, institutional legitimacy (verification that the organisation has respected its 'rules', status, mission, action programme) and the legal rules applicable to its legal form should be communicated to its stakeholders (Bagnoli \& Megali, 2011). The transparency of the governance process and its relationship with the mission and vision are seen as of particular importance by the main stakeholders of NGO (GRI 4, 2013).

Institutional legitimacy (verification that the organization has respected its 'rules', status, mission, action programme) and the legal rules applicable to its legal form should be communicated to its stakeholders (Bagnoli \& Megali, 2011). The purpose of NPO is public benefit, but general terms and benefits are defined in various ways, as a result of which there are specific regulations, laws, reports, and exemptions from taxes and fees (Pointer \& Orlikoff, 2002). In addition, the activities carried out by these organisations cover a wide range of stakeholders: donors of funds, both public and private, project and activity beneficiaries, persons related to those beneficiaries, volunteers, workers, among others. All these groups require information about the activities carried out by organisations with which they have some relationship (Santos, Ferreira, Marques, \& do Carmo Azevedo, 2018).

These organisations have a moral obligation to meet the informational needs of these groups, in short, they have an obligation to be transparent. NPO should transmit the added value provided by their activities to society, implementing the actions they consider necessary to do so, and which result in greater transparency (Cabedo, FuertesFuertes, Maset-LLaudes, \& Tirado-Beltrán, 2018).

\section{Research Methodology}

This paper aims to answer the following research question: Are IPSS prepared to meet management requirements by increasing your accountability?

To substantiate the fieldwork, a semi-structured interview script was established, based on a previous bibliographic review. The script used for the interviews is part of the Appendix A. In qualitative studies, fieldwork is often used to engage with the phenomenon for gathering information/data or for analysing in situ practices Appendix B.

To be successful, however, fieldwork must be preceded by prior planning when the object and purpose of the research are clarified (Feldman, 2019), who will be investigated and what will be investigated, and also, how it will be investigated, which implies the structuring of a roadmap of questions (Jacob \& Furgerson, 2012). These steps, added to the definitions of the respondents' approach, comprise the research protocol presented in Although aiming to answer the questions identified below, the interview should be conducted in a relaxed manner. Asking generic questions that allow us to get the answers to the questions below.

1. Characterisation

- the social mission of the institution; 
- the activities developed in the institution;

- the number of users covered by the activities;

- the evolution of the institution;

- the major transformations in the activity, if any, and what led to these transformations (a form of institution consolidation: enlargement/retraction).

2. Internal management models

- human resources in management positions

- composition of management positions

- decision-making processes

- performance evaluation

- existence of a quality management system

- $\quad$ strategic planning implementation

- the respondent's perception of the importance of transparency

\subsection{Sample definition and data collection}

Fieldwork would not be feasible with all entities of the IPSS population (5.358) at the time. Thus, a representative sample of the study population was defined, following the appropriate statistical procedures. Thus, to define the number of IPSS included in the sample, the Epi info software version 7.1.0.6 (Dean, Dean, Burton, \& Dicker, 1991) was used adopting a $90 \%$ confidence level and a margin of error of 5\% resulted in 258 IPSS to be interviewed. This number still seemed not feasible, so increasing the margin of error to $10 \%$, passing the number of IPSS to interview to 67 . However, depending on the availability of the respondents; the vacation period of the institutions, only 31 visits were made. The interviews were scheduled in the month of May 2019, and the visits took place in June and July 2019.

Several other questions were raised: the legal nature, the type of social responses; the dimension of the IPSS; geographical area; and eventually others.

\subsection{Methodology for Data Analysis}

The interviews were digitised, and the analysis of the fieldwork data was adopted. The Methodology of Content Analysis was adopted (Bardin, 2004), with the help of the Program NVivo12 Version 12.6.0. The choice of this software is related to the possibility of encoding and categorising various data formats, minimising the investigator's bias.

\section{Data Analysis}

In the content analysis process, the main ideas of the interviews were identified, grouped by similarity into five stages. In the first, the respondents were coded. To maintain data confidentiality, the IPSS name has been replaced by the acronym IPSS and numbered from 1 to 31. The Analysis Units, or Units of Record (UR), were identified in the second stage. In the third step, the Ur were grouped into categories, according to Table 1.

In the fourth stage, the categories were analysed, and, in the fifth, they were interpreted.

Table 1. Identification of Categories

Registration Units (UR)

Categories

UR1 - Identity of the investigated organisation

UR2 - Primary activities and support activities

UR3 - Values

C1 - Organisational Identity

UR4 - Transformations

UR5 - Number of Users 


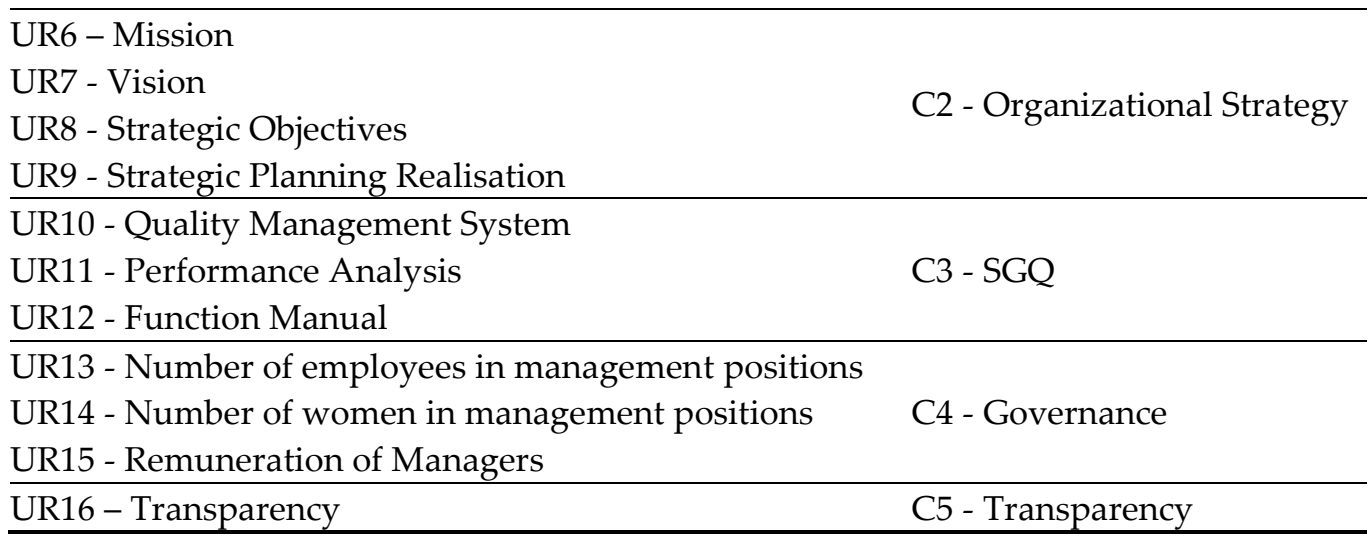

\subsection{C1 - Organisational Identity}

All the entities surveyed have a clear view of their main activities and are oriented to this end. As for the support activities, it was identified that four IPSS carry out support activities for the Social Security Institute (ISS), but without any remuneration. Some of the investigated elderly homes (IPSS8, IPSS9) and educational institutions (IPSS 1, IPSS 7, IPSS8) have part of their activities supported by a particular (for-profit) activity. In addition, the IPSS reported performing instrumental activities, such as social stores (IPSS7, IPSS26), canteens (IPSS13, IPSS21), sale of products for recycling (IPSS13), rental of space for events (IPSS7), paid tours (IPSS6, IPSS13, IPSS26). These activities guarantee additional money that is reverted to the institution.

As for the profile of the organisations interviewed, it was identified that:

- Many have their origins in some religions:

- IPSS1, the Anglican church;

- IPSS6, IPSS11, IPSS12, IPSS17, IPSS18, IPSS25, Catholic Church; and

- IPSS23, evangelical church.

- $\quad$ Some are rooted in community solidarity:

○ IPSS6, IPSS9, IPSS10, IPSS14, IPSS15, IPSS19, IPSS25, IPSS26, IPSS27, IPSS28, IPSS29, IPSS30, IPSS31.

- Two were raised by parents and are linked to mental and physical health:

- IPSS2 and IPSS3

- Entities that provide activities for the elderly, such as day centres, have some historical relationship with groups of workers:

- IPSS5 and IPSS13.

Another point to note is that many institutions that started their activities focusing on childhood have extended their actions to the care of the elderly (day centre, nursing homes, home care services) (IPSS7, IPSS8, IPSS30) and vice-versa (IPSS5, IPSS14).

The IPSS4, IPSS6, IPSS14, IPSS15, IPSS 18, IPSS 19, IPSS 20, IPSS 22, IPSS 29 and IPSS 31 , do not have clearly defined values, in the other IPSS, it was possible to identify the repetition of the following words:

- $\quad$ respect (14);

- $\quad$ solidarity (13);

- $\quad$ responsibility (7);

- cooperation (6);

- $\quad$ ethics (6);

- dignity (5);

- $\quad$ transparency (5);

- $\quad$ equality (5);

- $\quad$ confidence (4);

- $\quad$ quality (3); and

- Christian(s) (3).

4.2. C2 - Organizational Strategy 
Following legal proceedings, the IPSS visited have a clearly defined mission and made available on the website or Facebook of the institution. The exception is for IPSS21 and IPSS26 that do not have a mission statement. The interviewees knew of the existence of the mission, but they could not state their terms. The investigation team analysed the mission statements of the other twenty-nine entities interviewed and realised that only in the mission statements of IPSS22, IPSS25 and IPSS29 do not contain three items considered fundamental: what they do, how they do it and for whom they do it.

Of the 31 IPSS investigated, $21(67.7 \%)$ have a clearly defined vision, i.e., a future perspective for the institution. The vision, in 4 IPSS, may have improvements, and six (19.4\%) do not have a clearly defined vision. Despite this result, not all surveyed organisations are aware of the real importance/meaning of having a vision outlined.

Among the 31 entities interviewed, only $26 \%$ carry out strategic planning. Since IPSS31 does not do so in a systematic manner, IPSS12 claims the need to improve the process, and IPSS23 is in the implementation phase.

Among those that do not carry out strategic planning (74\%), IPSS12 realises the need to do so, IPSS13 states that the president 'does it in his head', IPSS15 states that it only makes the budget due to obligation, IPSS16 only does it on-demand, IPSS21 'lives the dayto-day', IPSS does not have one but considers it interesting, and IPSS31 says that 'Used to have one, but with the reduction of staff and users, it no longer does it'.

\subsection{C3 - Quality Management Systems}

Only two of the IPSS investigated have a quality management system. IPSS8 is certified by ISO 9001/2015 and is transversal to all responses, and IPSS12 has the Equass European Quality in Social Service program. Among the thirty-one IPSS investigated, only 12 have an institutionalised performance evaluation system, and IPSS14 replied that:

"Yes, but this past year it was not done. This year it went wrong because we wanted to get our model right. It was because we do not think it was fair. After all, we do the group evaluation and self-assessment, and often self-assessment puts the average up. We want to change it in order not to give too much focus to self-assessment. The weight of self-assessment is too high. The staff react well. There was a year where they did not react well because someone said they did not like a person, and it did not go well." (IPSS14)

IPSS10 claimed to have an informal evaluation system and 18 do not have performance evaluation, and IPSS 1 is in course of implementation; and the respondents of IPSS2, IPSS25 and IPSS31 regret the fact that they do not have one. IPSS9 stopped doing it and commented that 'it can never be done well'. According to IPSS 21:

“The official way, we do not have it. The board is talking, getting to know the problems of the clients. But it has been carried out informally. Perhaps it is implemented with the new management. There is no employee's performance evaluation. I am not aware that a form of evaluation is defined because we cannot confront an employee without a system of rules. We do not argue to evaluate. There has to be a set of predefined goals. The new direction is discussing this."

None of the IPSS investigated claimed to have a manual of functions identifying tasks, responsibilities, and autonomies.

\subsection{C4 - Governance}

When asked about the values present in the management of the entities, ten $(32.2 \%)$ of them did not have or did not answer the question. Among those who answered, 33.3\% mentioned the word ethics in their organisational values.

As for the presence of women in the management boards, contrary to what happens in the operational areas, where the massive predominance is of women, it was observed that men are the majority. Furthermore, even when there are women in management positions, they hold less prominent positions such as substitutes or secretaries of the bureau. In only 10 of the 31 entities interviewed were identified women as chairman of the board: IPSS2, IPSS4, IPSS7, IPSS8, IPSS14, IPSS16, IPSS18, IPSS23, IPSS25, IPSS28. 
It should be considered, however, that in parish social centres, usually, the presidency is exercised by a priest of the Catholic Church.

Concerning the wage issue, Portuguese legislation imposes some limitations on the payment of salaries of directors of social bodies, as noted in the theoretical framework. However, the chairman of the board of IPSS12 is remunerated and exercises the role of chairman of the board in five other IPSS belonging to the Catholic Church. It was not possible to identify whether non-financial benefits are offered to the occupants of management positions.

Finally, regarding the participation of workers, non-members, in the social bodies, again the Portuguese legislation imposes restrictions, so we do not find workers in the social bodies. It is worth mentioning, however, that representatives of the governing bodies were identified performing operational tasks. This situation was observed in the IPSS: IPSS6, IPSS7, IPSS9, IPSS15, IPSS16, IPSS21, IPSS25, IPSS26, IPSS28, IPSS29, IPSS30 and IPSS31.

\subsection{C5 - Transparency}

When asked if the existence of a microsite can increase the transparency of IPSS, out of the 31 IPSS interviewed, 20 answered yes. They believe that owning a website increases the transparency of the institution.

IPSS1 believes that 'transparency and social impact are imperative to 'sell' IPSS and reach other spheres (enterprise-level), and the community'. IPSS3, IPSS11, IPSS13, IPSS23 and IPSS27 stated that they are already transparent in disclosing their information.

IPSS21 trusts that 'we have to seek transparency', and IPSS8 suggests that transparency 'can put institutions on an equal footing' and facilitates the exchange of information between institutions. 'In a company, we can do, in the social area this is more difficult'.

IPSS26 suggests that IPSS are not transparent: 'Will everyone be transparent in disseminating information?' 'Today, we know it is not like that'.

Furthermore, IPSS31 states that 'there are things we cannot put on the site. Ideas, projects, things that are in our thoughts. We have some antibodies in the village that we must neutralise'.

\section{Results}

This paper sees you as a goal to ascertain whether IPSS is prepared to meet management requirements by increasing your accountability. Rendering Bartlett and Ghoshal (1994), the central concepts in the study on business management include understanding the strategy and purpose of the organisation. According to Young (2001), the central concepts in the study on business management include understanding the strategy and purpose of the organisation. That said, this study sought to investigate the policies and practices adopted by the investigated institutions, through semi-structured interviews, conducted with the leaders of the institutions. From the answers were extracted the reference units (UR), which allowed to make up five categories: C1. organizational identity; C2. organizational strategy; C3. Quality Management System; C4. Governance; and C5. Transparency.

With regard to organizational identity, it was identified that the institutions have knowledge of their social importance, dominate the activities carried out, and often depend on an additional effort to ensure the financial sustainability of their activities. Among these activities are reported not only commercial activities (or exchange), but also the involvement of some presidents of management in the conduct of operational activities in the day-to-day of the institution, in order to save on expenses with the hiring of personnel, a fact that was clearly mentioned during some interviews. In most of them, it is noticeable the influence of its founders, which goes against the ideas of Young (2001) and Werther and Berman (2001), which suggest that over the years the identity of the institution can distance itself from the vision of its founders. On the contrary, there was a strong presence of the ideas and social ambitions of the founders of these institutions. 
In the operational strategy category, except for educational institutions, the analysis of UR has identified that there is no concern about increased competition between IPSS, as suggested by Al-Tabbaa, Gadd and Ankrah (2013) and Cairns et al. (2005). On the contrary, it became evident the need to form networks to complement knowledge and needs. Most of the entities interviewed do not have structured strategic planning, even recognising that the realisation of the planning may be necessary for the institution. Usually, their managers are involved with the short term, or else, the management is so far away, they do not realise there is a competition or other issues related to strategic planning. The missions analysed included the three components suggested by the literature (what, who and how), however, most respondents did not know the mission, although all worked to meet the institution's purposes. Moore (2000) defends the importance of strategic planning to ensure its effectiveness and the achievement of its purposes.

Concerning category $\mathrm{C} 3$, it was perceived that the institutions recognise the importance of having a QMS, meeting Kong (2008) and Bou-Llusar et al. (2005) arguments, which draw attention to the fact that QMS can contribute to improving organisational performance. Despite this, it was noticed that an incipient number of institutions that have QMS and manual functions, while concerning the existence of a performance manual, the percentage was slightly higher. It is interesting to note the response of two institutions investigated:

"No. We are still in development, but it is a very complex area. Performance evaluation can be a conflict area. This may be a pandora's box, but we create injustices both when we do it and when we don't." (IPSS5)

"I have tried because I think it is important. Nevertheless, we do not. I am good at evaluating, but without a methodology, people end up feeling bad." (IPSS29)

Concerning the governance of entities, the interviewees' discourse was clearly in favour of ethics and transparency on the company's management. Only one of the presidents interviewed was in a paid position, as he reported being president and employee of the institution, making the situation a little nebulous since he received a salary as an employee. In one of the institutions interviewed, the respondent stated that the president preferred to keep in his residence donated paintings 'to prevent them from being damaged'. Concerning gender equity, it was observed that: (i) operational positions are notably occupied by women, and the justification is since women prefer to be cared for by women, (ii) the presence of women in management positions is much smaller than that of men, around $15-20 \%$, even when considering that women in the position of management presidency correspond to $30 \%$, (iii) in religious institutions (Parish Social Centres) the positions of the presidency are occupied mainly by priests, which contributes to the reduction of the number of women in CEO positions.

All institutions have reported the importance of transparency, C5, and understand that ethics and transparency only corroborate to strengthen the institution's reputation, contributing to the raising of funds, attracting new donors and users.

Two limitations were perceived in this research. The first concerns the period in which the interviews were conducted: close to the vacation period. This work is expected to contribute to the research gap related to social indicators, specially, non-financial indicators and assist SE organisations in their management process and accountability. The second concerns the respondents' work overload, who were not always available to attend the research team.

This section may be divided by subheadings. It should provide a concise and precise description of the experimental results, their interpretation, as well as the experimental conclusions that can be drawn.

Author Contributions: Conceptualization, Augusta Ferreira, Graça Azevedo, Alberto J. Costa and Rui Pedro Marques; methodology, Denise Cury, Brizida Tomé and Carla Joaquim; software, Carlos Santos, Rui Pedro Marques and Rúben Duarte; validation, Graça Azevedo, Denise Curi, Alberto J. Costa, Brizida Tomé, Carla Joaquim and Rui Pedro Marques; formal analysis, Graça Azevedo, 
Denise Curi, Alberto J. Costa, Brizida Tomé, Carla Joaquim and Rui Pedro Marques; investigation, Graça Azevedo, Denise Curi, Alberto J. Costa, Ana Maria Bandeira, Augusta Ferreira, Brízida Tomé, Carla Joaquim, Carlos Santos, Cristina Góis, Deolinda Meira, Helena Inácio, Mafalda Jesus, Maria Goreti Teixeira, Patrícia Monteiro, Rúben Duarte and Rui Pedro Marques; resources, Ana Maria Bandeira, Augusta Ferreira, Carlos Santos, Cristina Góis, Deolinda Meira, Helena Inácio, Mafalda Jesus, Maria Goreti Teixeira and Patrícia Monteiro and Ruben Duarte; data curation, Ana Maria Bandeira, Augusta Ferreira, Carlos Santos, Cristina Góis, Deolinda Meira, Helena Inácio, Mafalda Jesus, Maria Goreti Teixeira and Patrícia Monteiro; writing - original draft preparation, Denise Curi and Brizida Tomé; writing - review and editing, Graça Azevedo, Alberto J. Costa, Carla Joaquim and Rui Pedro Marques; visualization, Graça Azevedo, Alberto J. Costa, Carla Joaquim and Rui Pedro Marques; project administration, Augusta Ferreira, Rui Pedro Marques; funding acquisition, Augusta Ferreira. All authors have read and agreed to the published version of the manuscript."

Funding: Program (COMPETE 2020 - POCI), and the Foundation for Science and Technology (FCT): POCI-01-0145-FEDER-030074

Acknowledgments: The European Regional Development Fund (ERDF), through the Operational Competitiveness and Internationalisation Programme (COMPETE 2020 - POCI), and the Foundation for Science and Technology (FCT) financed this research, with the reference number POCI-010145-ERDF-030074

Conflicts of Interest: The authors declare no conflict of interest. The funders had no role in the design of the study; in the collection, analyses, or interpretation of data; in the writing of the manuscript, or in the decision to publish the results. 


\section{Appendix A}

1entities

Although aiming to answer the questions identified below, the interview should be conducted in a relaxed manner. Asking generic questions that allow us to get the answers to the questions below.

3. Characterisation

- the social mission of the institution;

- the activities developed in the institution;

- the number of users covered by the activities;

- the evolution of the institution;

- the major transformations in the activity, if any, and what led to these transformations (a form of institution consolidation: enlargement/retraction).

4. Internal management models

- human resources in management positions

- composition of management positions

- decision-making processes

- $\quad$ performance evaluation

- existence of a quality management system

- strategic planning implementation

- the respondent's perception of the importance of transparency

\section{Appendix B}

\section{Protocol for fieldwork}

1. scheduling of the meeting whose initial contact was made by telephone;

2. training of teams with two researchers;

3. sending an e-mail to the directors of the institutions confirming the appointment;

4. a quick internet search to verify if the institution had a website.

5. at the beginning of the meeting with the entity, the group adopted the following procedure:

- thank the availability of the institution;

- present the project, with emphasis on two points:

○ talk about the constitution of the project team;

$\circ$ present the project summary mentioning its objectives;

6. at the end of the interview, the group of researchers:

- showed the site, for all entities, and collected suggestions;

- sought opinions on the usefulness of the project;

- investigated the availability of the project, and whether or not to have a website, whether she would be interested in having a microsite;

- would appreciate the contact and indicate the next step; and

- committed to keeping the institution abreast of the development of the project.

\section{References}

Aimers, J., \& Walker, P. (2008). Is community accoutability being overlooked as a result of government-third sector partnering in New Zealand. Aotearoa New Zealand Social Work, 20(3), pp. 14-24.

Albert, S., \& Whetten, D. A. (1985). Organizational Identity. Research in Organizational Behavior, 7, pp. $263-295$.

Allison, M., \& Kaye, J. (2015). Strategic planning for nonprofit organizations: A practical guide for dynamic times. John Wiley \& Sons. 
Al-Tabbaa, O. (2012). Nonprofit-businesses collaboration: thematic review and new research agenda. Retrieved January 2021, from https://papers.ssrn.com/sol3/papers.cfm?abstract_id=2191540

Al-Tabbaa, O., Gadd, K., \& Ankrah, S. (2013). Excellence models in the non-profit context: strategies for continuous improvement. International Journal of Quality \& Reliability Management, 30(5), pp. 590-612. DOI 10.1108/02656711311315521.

Bagnoli, L., \& Megali, C. (2011). Measuring performance in social enterprises. Nonprofit and Voluntary Sector Quarterly , 40(1), pp. 149165. doi: $10.1177 / 0899764009351111$.

Bardin, L. (2004). Análise de conteúdo 3a. Ed. Lisboa: Edições 70.

Bartlett, C. A., \& Ghoshal, S. (1994). Changing the role of top management: Beyond strategy to purpose. Harvard Business Review, 72(6), pp. 79-88.

Becker, A. (2018). An Experimental Study of Voluntary Nonprofit Accountability and Effects on Public Trust, Reputation, Perceived Quality, and Donation Behavior. Nonprofit and Voluntary Sector Quarterly, 47(3), pp. 562- 582. https://doi.org/10.1177/089976.

Bou-Llusar, J., Escrig-Tena, A. B., Roca-Puig, V., \& Inmaculada, B.-M. (2005). To what extent do enablers explain results in the EFQM excellence model? An empirical study. International Journal of Quality E Reliability Management, 22(4), pp. 337-353. DOI 10.1108/02656710510591192.

Bovens, M. (2016). Analysing and assessing accountability: a conceptual framework. European Law Journal, 13(4), pp. 447-468. https://doi.org/10.1111/j.1468-0386.2007.00378.x.

Bryce, H. J. (2017). Financial and strategic management for nonprofit organizations. Walter de Gruyter GmbH \& Co KG.

Bryson, J. M. (2018). Strategic planning for public and nonprofit organizations: A guide to strengthening and sustaining organizational achievement. John Wiley \& Sons. 544p.

Cabedo, J. D., Fuertes-Fuertes, I., Maset-LLaudes, A., \& Tirado-Beltrán, J. M. (2018). Improving and measuring transparency in NGOs: A disclosure index for activities and projects. Nonprofit Management and Leadership, 28(3), pp. 329-348.

Cairns, B., Harris, M., Hutchison, R., \& Tricker, M. (2005). Improving performance? The adoption and implementation of quality systems in UK nonprofits. Nonprofit Management and Leadership, 16(2), pp. 135-151. https://onlinelibrary.wiley.com/doi/abs/10.1002/nml.97.

Campbell, A., \& Alexander, M. (1997). What's Wrong with Strategy? Harvard Business Review, 75(6),. 75(6), pp. 42-51. Retrieved from http://search.ebscohost.com/login.aspx?direct=true\&db=bth\&AN=9711071075\&lang=pt-pt\&site=ehost-live.

Choudhury, E., \& Ahmed, S. (2002). The shifting meaning of governance: Public accountability of third sector organizations in an emergent global regime. International Journal of Public Administration, 25(4), pp. 561-588. https://doi.org/10.1081/PAD120013256.

Claeyé, F., \& Jackson, T. (2012). The iron cage re-revisited: Institutional isomorphism in non-profit organisations in South Africa. Journal of International Development, 24(5), pp. 602-622.

Connolly, C., \& Kelly, M. (2011). Understanding accountability in social enterprise organisations: a framework. Social Enterprise Journal , 7(3), pp. 224-237 doi: 10.1108/17508611111182386.

Crucke, S., \& Decramer, A. (2016). The development of a measurement instrument for the organizational performance of social enterprises. Sustainability, 8(2), p. 161 doi: 10.3390/su8020161.

Dean, A. G., Dean, J. A., Burton, A. H., \& Dicker, R. C. (1991). Epi Info: a general-purpose microcomputer program for public health information systems. American journal of preventive medicine, 7(3), 178-182. https://doi.org/10.1016/S0749-3797(18)30936-X.

Drucker, P. F. (1973). Management: Tasks, responsibilities, practices . New York: Harper \& Row.

Edwards, M., \& Hulme, D. (1995). Non-governmental organisations: performance and accountability beyond the magic bullet. Earthscan.

EU. (2021). Social Economy in European Union. Retrieved from European Comission: https://ec.europa.eu/growth/sectors/socialeconomy_en

Feldman, E. J. (2019). A practical guide to the conduct of field research in the social sciences. Routledge.

Freeman, R. E. (1999). Divergent stakeholder theory. Academy of management review, 24(2), pp. 233-236.

Friedman, M. (1970, September 13). The Social Responsibility of Business Is to Increase Its Profits. The New York Times Magazine. 
Gray, R., Owen, D., \& Adams, C. (2008). Accounting and accountability: changes and challenges in corporate social and environmental reporting. London: Prentice-Hall.

GRI 4. (2013). Sustainability Reporting Guideline G4: Implementation Manual. Global Reporting Innitiative.

Hall, M., \& O'Dwyer, B. (2017). Accounting, non-governmental organizations and civil society: The importance of nonprofit organizations to understanding accounting, organizations and society. Accounting, Organizations and Society, 63, pp. 1-5.

Hitt, M. A., Ireland, R. D., \& Hoskisson, R. E. (2012). Strategic management cases: competitiveness and globalization. Cengage Learning.

Ireland, R. D., \& Hitt, M. A. (1999). Achieving and maintaining strategic competitiveness in the 21st century: The role of strategic leadership. Academy of Management Perspectives, 13(1), pp. 43-57.

Jacob, S. A., \& Furgerson, P. S. (2012). Writing interview protocols and conducting interviews: tips for students new to the field of qualitative research. Qualitative Report, 17(6).

Kearns, K. P. (1994). The strategic management of accountability in nonprofit organizations: An analytical framework. Public Administration Review , pp. 185-1992. https://doi.org/10.2307/976528.

Kleinknecht, R. H. (2015). Employee participation in corporate governance: Implications for company resilience. European Journal of Industrial Relations, 21(1), pp. 57-72. doi: 10.1177 / 0959680114523820.

Kong, E. (2008). The development of strategic management in the non-profit context: Intellectual capital in social service non-profit organizations. International Journal of Management Reviews, 10(3), pp. 281-299. doi: 10.1111/j.1468-2370.2007.00224.x.

Lewis, F., Edwards, L. H., Lewis, B., G., \& McGinnis, J. (2013). An Analysis of Gender Pay Disparity in the Nonprofit Sector: An Outcome of Labor Motivation or Gendered Jobs? . Nonprofit and Voluntary Sector Quarterly, 42(6), pp. 1268-128. doi:10.1177/0899764012455951.

Moore, M. H. (2000). Managing for Value: Organizational Strategy in For-Profit, Nonprofit, and Governmental Organizations. Nonprofit E Voluntary Sector Quarterly, 29(1), pp. 183-208. https://doi.org/10.1177/0899764000291S009.

Oliveira, D. d. (2010). Planejamento estratégico: conceitos, metodologias e práticas. São Paulo : Atlas.

Peters, B. G. (1983). Philip AllenP. M. Jackson The Political Economy of Bureaucracy, Philip Allen, 1982, 296pp., £12.50. - W. S. Pierce Bureaucratic Failure and Public Expenditure, Academic Press, 1981, \$12.50. Journal of Public Policy, 3(4), pp. 435-436. doi:10.1017/S0143814X00007558.

Pointer, D. D., \& Orlikoff, J. E. (2002). The high-performance board: Principles of nonprofit organization governance. John Wiley \& Sons.

Porta, R. L., Lopez-de-Silanes, F., Shleifer, A., \& Vishny, R. w. (1998). Law and finance. Journal of political economy, 106(6), pp. 11131155.

Pynes, J. E. (2000). Are Women Underrepresented as Leaders of Nonprofit Organizations? . Review of Public Personnel Administration, 20(2), pp. 35-49. doi:10.1177/0734371X0002000204.

Rassart, C., \& Miller, H. (2013). The effetctive not-for-profit board: a value-driving force. Ottawa: Deloitte Centre for Corporate Governance.

Santos, C., Ferreira, A. D., Marques, R. P., \& do Carmo Azevedo, G. (2018). EAGLE_Index: Enhancement of an accountability guide for learning E-Government. Handbook of Research on Modernization and Accountability in Public Sector Management.

Sousa, S. (2012). As Instituições Particulares de Solidariedade Social num contexto de crise económica. Lisboa: IPI-Consulting Network Portugal.

Spear, R. (2004). Governance in Democratic Member-Based Organisations. Annals of Public and Cooperative Economics, 75(1), pp. 33-50. Speckbacher, G. (2003). The economics of performance management in nonprofit organizations. Nonprofit management and leadership, 13(3), pp. 267-281. https://doi.org/10.1007/s11187-011-9399-3.

Speckbacher, G. (2008). Nonprofit versus corporate governance: An economic approach. Nonprofit management and leadership, 18(3), pp. 295-320.

Themudo, N. S. (2009). Gender and the nonprofit sector. Nonprofit and Voluntary Sector Quarterly, 38(4), pp. $663-683$.

UN. (2021). Civil Society. Retrieved from United Nation: https://www.un.org/en/civil-society/page/about-us

Werther, W. B., \& Berman, E. M. (2001). Third sector management: The art of managing nonprofit organizations. Georgetown University Press. 
Wolf, M., \& Mair, J. (2019). Purpose, Commitment and Coordination Around Small Wins: A Proactive Approach to Governance in Integrated Hybrid Organizations. VOLUNTAS: International Journal of Voluntary and Nonprofit Organizations, 30(3), pp. 535548. https://doi.org/10.1007/s11266-019-00116-5.

Young, D. R. (2001). Organizational Identity in Nonprofit Organizations: Strategic and Structural Implications. Nonprofit Management $\mathcal{E}$ Leadership, 12(2), pp. 139-157. doi:10.1002/nml.12202.

Zainon, S., Ahmad, S. A., Atan, R., Wah, Y. B., Bakar, Z. A., \& Sarman, S. R. (2014). Legitimacy and Sustainability of Social Enterprise: Governance and Accountability. Procedia - Social and Behavioral Sciences, 145, pp. 152-157. doi: 10.1016/j.sbspro.2014.06.022. 